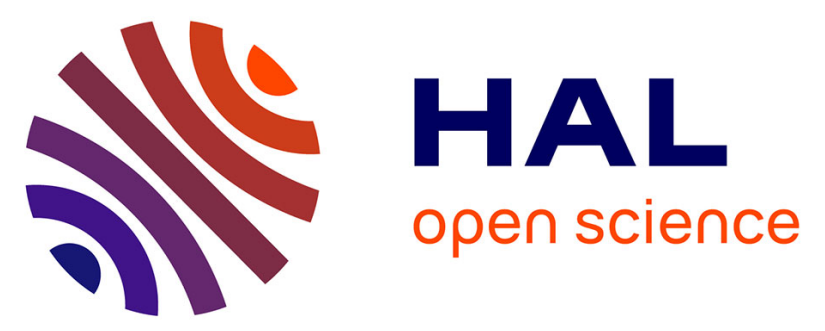

\title{
Interaction of oxycodone and voriconazole-a case series of patients with cancer pain supports the findings of randomised controlled studies with healthy subjects
}

Nora M. Hagelberg, Tuija H. Nieminen, Teijo I. Saari, Mikko Neuvonen, Pertti J. Neuvonen, Kari Laine, Klaus T. Olkkola

\section{To cite this version:}

Nora M. Hagelberg, Tuija H. Nieminen, Teijo I. Saari, Mikko Neuvonen, Pertti J. Neuvonen, et al.. Interaction of oxycodone and voriconazole-a case series of patients with cancer pain supports the findings of randomised controlled studies with healthy subjects. European Journal of Clinical Pharmacology, 2011, 67 (8), pp.863-864. 10.1007/s00228-010-0969-0 . hal-00658703

\section{HAL Id: hal-00658703 https://hal.science/hal-00658703}

Submitted on 11 Jan 2012

HAL is a multi-disciplinary open access archive for the deposit and dissemination of scientific research documents, whether they are published or not. The documents may come from teaching and research institutions in France or abroad, or from public or private research centers.
L'archive ouverte pluridisciplinaire HAL, est destinée au dépôt et à la diffusion de documents scientifiques de niveau recherche, publiés ou non, émanant des établissements d'enseignement et de recherche français ou étrangers, des laboratoires publics ou privés. 


\title{
Interaction of oxycodone and voriconazole - a case series in patients with cancer pain supports the findings of randomised controlled studies in healthy subjects
}

\author{
Nora M Hagelberg $^{1 *}$, Tuija H Nieminen ${ }^{1}$, Teijo I Saari ${ }^{1}$, Mikko Neuvonen ${ }^{2}$, Pertti J Neuvonen ${ }^{2}$, \\ Kari Laine ${ }^{3}$, Klaus T Olkkola ${ }^{1}$
}

${ }^{1}$ Department of Anaesthesiology, Intensive Care, Emergency Care and Pain Medicine, University of Turku and Turku University Hospital, Turku, Finland

${ }^{2}$ Department of Clinical Pharmacology, University of Helsinki and Helsinki University Hospital, Helsinki, Finland

${ }^{3}$ Department of Pharmacology, Drug Development \& Therapeutics, University of Turku, Turku, Finland

*Corresponding author. Mailing address: Department of Anaesthesiology, Intensive Care, Emergency Care and Pain Medicine, University of Turku, P.O. Box 52, FI-20521 Turku, Finland. Phone: +358-2-313 1269. Fax: +358-2-313 3270. E-mail: nora.hagelberg@tyks.fi

Key words: oxycodone, voriconazole, interaction, CYP3A

Metabolism of oxycodone via cytochrome (CYP) 3A and 2D6 makes individuals using oxycodone for pain relief prone to drug-drug interactions. Recent studies in healthy subjects show that in the elimination of oxycodone, CYP3A is more significant than CYP2D6. Inhibition of hepatic and/or intestinal CYP3A with voriconazole, itraconazole, ketoconazole, HIV protease inhibitors or grapefruit juice increases exposure to oral oxycodone in healthy subjects and may enhance its analgesic or adverse effects [1-8].

In this issue of European Journal of Clinical Pharmacology, Watanabe et al. describe a case report of a male patient with Burkitt's lymphoma who experienced enhanced analgesic and adverse effects of oxycodone during concomitant treatment of a systemic fungal infection with i.v. voriconazole [9]. In addition, they present a retrospective case series of eight other patients with cancer pain who were predisposed to an interaction between oxycodone and voriconazole. Six of these patients experienced drowsiness, vomiting or hypopnea within a few days after starting voriconazole treatment and in some patients, the need for additional doses of opioid diminished. In one patient, analgesia was inadequate after discontinuation of voriconazole. The adverse effects observed in 
patients were more typical for opioids than voriconazole. Based on the pharmacokinetic results of previous interaction studies conducted in healthy subjects, the authors conclude that the observed symptoms in their patients were due to increased oxycodone plasma concentrations caused by CYP3A inhibition by voriconazole.

Polymorphism of CYP2D6 has been suggested to influence the pharmacokinetic profile and analgesic effect of oxycodone. Two of the patients in the case series did not experience alterations in the effects of oxycodone during voriconazole treatment. In ultrarapid CYP2D6 metabolisers, oxycodone concentrations have remained low even during concomitant administration of CYP3A inhibitors $[1,5,6]$. It is thus theoretically possible that one or both of these patients were ultrarapid metabolisers of CYP2D6. Similarly, drugs inhibiting CYP2D6 or the poor metaboliser CYP2D6 genotype, may partly explain the observed findings in patients with exaggerated opioid effects.

Although interaction studies of opioid analgesics in healthy subjects are useful and provide accurate pharmacokinetic data, there are limitations especially when it comes to assessing the impact of the interaction on the analgesic effect of the drug. The doses of opioids in studies in healthy subjects have to be kept substantially lower than what can be seen in clinical reality. On the other hand, experimental pain tests do not always correlate very well with clinical pain for a variety of reasons, and the log-linear relationship between drug concentration and effect may further hamper the interpretation. Because the main focus of studies conducted in healthy subjects is on the pharmacokinetic interaction, these studies are often underpowered in terms of demonstrating significant differences in pharmacodynamic measurements.

It is challenging to study drug-drug interactions in all clinical patient populations, especially in those who are critically ill or require multiple medications. Patient data from case series of clinical drug-drug interactions such as that presented by Watanabe et al. are valuable as they test the clinical applicability of interaction studies conducted in healthy subjects.

\section{Conflict of interest}

Dr. Klaus T Olkkola has worked as a pharmacokinetic consultant for Akela Pharma Inc., Turku, Finland. Kari Laine is shareholder of Medbase Ltd. Other authors declare that they have no conflicts of interest. 


\section{References}

1. Hagelberg NM, Nieminen TH, Saari TI, Neuvonen M, Neuvonen PJ, Laine K, Olkkola KT (2009) Voriconazole drastically increases exposure to oral oxycodone. Eur J Clin Pharmacol $65: 263-271$

2. Grönlund J, Saari TI, Hagelberg NM, Neuvonen PJ, Laine K, Olkkola KT (2010) Exposure to oral oxycodone is increased by concomitant inhibition of CYP2D6 and CYP3A pathways but not by inhibition of CYP2D6 alone. Br J Clin Pharmacol 70:78-87

3. Nieminen TH, Hagelberg NM, Saari TI, Neuvonen M, Neuvonen PJ, Laine K, Olkkola KT (2010) Oxycodone concentrations are greatly increased by the concomitant use of ritonavir or lopinavir/ritonavir. Eur J Clin Pharmacol 66:977-985

4. Nieminen TH, Hagelberg NM, Saari TI, Neuvonen M, Neuvonen PJ, Laine K, Olkkola KT (2010) Grapefruit juice enhances the exposure to oral oxycodone. Basic Clin Pharmacol Toxicol 107:782-788

5. Saari TI, Grönlund J, Hagelberg NM, Neuvonen M, Laine K, Neuvonen PJ, Olkkola KT (2010) Effects of itraconazole on the pharmacokinetics and pharmacodynamics of intravenously and orally administered oxycodone. Eur J Clin Pharmacol 66:387-397

6. Samer CF, Daali Y, Wagner M, Hopfgartner G, Eap CB, Rebsamen MC, Rossier MF, Hochstrasser D, Dayer P, Desmeules JA (2010) The effects of CYP2D6 and CYP3A activities on the pharmacokinetics of immediate release oxycodone. Br J Pharmacol 160:907-918

7. Kummer O, Hammann F, Moser C, Schaller O, Drewe J, Krähenbühl S (2010) Effect of the inhibition of CYP3A4 or CYP2D6 on the pharmacokinetics and pharmacodynamics of oxycodone. Eur J Clin Pharmacol. doi10.1007/s00228-010-0893-3

8. Samer CF, Daali Y, Wagner M, Hopfgartner G, Eap CB, Rebsamen MC, Rossier MF, Hochstrasser D, Dayer P, Desmeules JA (2010) Genetic polymorphisms and drug interactions modulating CYP2D6 and CYP3A activities have a major effect on oxycodone analgesic efficacy and safety. Br J Pharmacol 160:919-930 
9. Watanabe M, Homma M, Momo K, Okoshi Y, Wada T, Hara A, Chiba S, Kohda Y. Effects of voriconazole co-administration on oxycodone-induced adverse effects - a case in the retrospective survey. Eur J Clin Pharmacol 